Drugs and Alcohol Today, 2013, Volume 13, Issue 1

Pages $20-27$

DOI: http://dx.doi.org/10.1108/17459261311310817

This article is (C) Emerald Group Publishing and permission has been granted for this version to appear here (http://dspace.mah.se/). Emerald does not grant permission for this article to be further copied/distributed or hosted elsewhere without the express permission from Emerald Group

Publishing Limited. www.emeraldinsight.com

\title{
The moral entrepreneurship of anti-khat campaigners in Sweden - A critical discourse analysis
}

\author{
Johan Nordgren \\ Department of Social Work, Malmö University, Malmö, Sweden
}

\begin{abstract}
Purpose - This article aims to analyse the discourse about khat in the Swedish newspaper media and to present the concept of moral entrepreneurship as a useful analytical tool for understanding mobilisation against khat use in the Somali diaspora.

Design/methodology/approach - The material analysed consists of daily newspaper articles about khat published between 1986 and 2012. The method of analysis is inspired by the critical discourse analysis framework developed by Norman Fairclough. Drawing on Howard S. Becker's concept of moral entrepreneur, the article focuses on anti-khat campaigners who speak out against khat in the media. These are often representatives from Somali voluntary associations or organisations, who sometimes employ moral entrepreneurship. The article discusses these actors' role in framing khat use as a tangible threat to the Somali community in Sweden.

Findings - When employing moral entrepreneurship, anti-khat campaigners spread a certain type of knowledge about khat that is presented to the general public via the media. The key issues that repeatedly are of concern are how khat destroys Somali families and how the use might spread to other groups. In this manner khat use is constructed as a threat to Somali social cohesion. The knowledge produced could potentially influence policy makers to introduce stricter punishments for possession, sale and use of khat, thereby possibly increasing stigma and marginalisation in relation to the Somali immigrant community.

Originality/value - The literature about khat has pointed to the centrality of Somali organisations mobilising against khat in the diaspora. This article presents moral entrepreneurship as a theoretical tool to further the understanding of the mobilisation against khat and its use.
\end{abstract}

Keywords: Khat, Moral entrepreneur, Critical discourse analysis, Somali diaspora, Sweden, Drugs, Social groups, Immigrants, Public policy

\section{Introduction}

The number of persons born in Somalia living in Sweden has increased during the last decade. In 2000 there were 13082 Somalis living in Sweden, in 2011 the number was 40 165. Minority immigrant groups in Sweden have traditionally organised themselves by forming voluntary associations, often with the goal of strengthening the position of the group in society. Voluntary associations are free to apply for public funding to facilitate their activities and the official view is that these associations can improve political integration into Swedish society (Bengtsson 2004: 12). They must meet certain conditions to be eligible for funding, for example having a democratically elected board and a chairman (Odmalm 2004: 115). The Somali national association in Sweden states that there are more than 50 local chapters in the country ${ }^{2}$, but there are probably many more associations since there is no requirement to register if public funding is not applied for. It is not uncommon for these associations to seek public funding for projects 
against khat use within the community. I argue that this type of mobilisation can be identified as moral entrepreneurship, which will allow for a more complex understanding of anti-khat sentiments in the diaspora.

Khat consists of the leaves and stalks of the khat plant (Catha edulis), which is mainly cultivated in East Africa. The leaves of the plant are chewed for their stimulating effect, causing a mild intoxication comparable to the effects of amphetamine (ACMD 2005: 17). Generally, the practise of chewing khat is gender segregated, it is mostly men who chew, although there have been reports of increased use among women in some countries (Feigin et al. 2012: 290; Anderson et al. 2007: 157). The use of khat is centred in countries such as Somalia, Kenya and Ethiopia in East Africa and Yemen on the Arabian Peninsula. As migration from these countries to Europe and North America has increased, the export of khat to the West has increased as well (Klein et al. 2009: 509). This export relies on fast and efficient transportation networks since the psychoactive constituents in the leaves (cathinone and cathine) degrade rather quickly, meaning that the leaves preferably should be as fresh as possible (Anderson et al. 2007: 165).

The use of khat is criminalised in the whole of Scandinavia; khat was classified as a narcotic substance in Sweden and Norway in 1989 (Gundersen 2006: 56) and in Denmark in 1993 (Pedersen \& Toudahl 2008: 19). The first convictions for smuggling khat into Sweden date to 1990 (TT, 29 January, 1990). It is worth noting that the criminalisation of khat in Sweden occurred before the first major wave of Somali refugees arrived in the early to the mid-1990's. The very first Somali immigrants came to Sweden at the end of the 1960's (Melander 2009: 15), but there is no evidence to suggest that this group imported khat to Sweden. Classifying khat as a narcotic substance was in all likelihood intended to align Swedish law with the UN listing of cathinone and cathine in Schedules I and III in the Convention on Psychotropic Substances of 1971.

Research on khat use in Sweden, albeit limited, has registered a sense of ambivalence within the Somali community. In one qualitative study of eight men and six women (Osman \& Söderbäck 2011) khat was seen as food, not to be compared to drugs of different kinds and as a part of Somali culture. Khat was perceived as having both positive and negative physical effects that could differ from individual to individual (cf. Sykes et al. 2010). That khat causes social problems was a widely held view among the interviewees, nonetheless, khat was seen as medium of community cohesion (Osman \& Söderbäck 2011).

\section{Method and data}

The method used for analysis is critical discourse analysis (CDA) inspired by the works of Norman Fairclough (Fairclough 1992; 1995). The main theoretical premise of the CDA framework is that production and consumption of texts constitutes an important social practice. Specific to Fairclough's framework is the notion that texts, such as newspaper articles, are both constituted by social practices and constitute the social world. For example, the discourse about khat as produced in daily newspaper articles creates a certain type of knowledge about khat use. The actual practice of khat use forms the basis for the production of these texts which then construe a specific type of knowledge in the minds of readers. By emphasising this 'dialectical' approach to discourses and social practises, the social phenomenon in question can be studied in a more complex fashion (Fairclough 1992: 65).

A total of 33 articles published in Swedish daily newspapers between 1986 and 2012 were collected from a full text news database that indexes articles from a majority of all Swedish daily newspapers. Searches conduced on the actual websites of the major daily newspapers in Sweden yielded a few articles not indexed in the full text news database. One limitation regarding this method of data gathering is the potential exclusion of articles not indexed in the databases; searches in physical archives have not been conducted, hence most articles date from the mid- to 
late 2000's. The majority of the articles are longer investigative reports, 7 articles were classified as press items or opinion pieces. The criterion used for including an article was that the central theme was khat use, while articles on Somali immigrants living in Sweden with only cursory mentions of khat were excluded. While media reporting on khat is a recurrent feature, it is of marginal concern and hardly merits the label 'moral panic' (cf. Cohen 1972/2002).

\section{The moral entrepreneurship of the anti-khat campaigners}

Howard S. Becker introduced the concept of the moral entrepreneur (Becker 1963/1991) arguing that rules and regulations within society are the result of actions taken by groups or individuals who draw attention to a certain social issue. In an ideal type fashion, Becker distinguishes between rule creators and rule enforcers. The rule creator is characterised as a goal-oriented 'crusader' who wants to push his or her moral stance on others in relation to the specific issue that is first identified and then problematised. This can mean new or more punitive laws, or as in the case of drugs, developing, publishing and legitimating specific images of a drug as particularly dangerous. The key point Becker makes concerning the rule enforcers (for example police officers) is that they tend not to be as active in enforcing the specific rule that the rule creators have put in place. The case of khat in Sweden offers a good example of this, anti-khat campaigners claim that the police and customs are doing too little to curb the smuggling, sale and use of khat (cf. Klein \& Metaal 2010: 586). I refrain from labelling the anti-khat campaigners as moral entrepreneurs since this can be viewed as pejorative. Instead I argue that we should investigate how individuals sometimes, and within certain contexts and situations, can employ moral entrepreneurship. The central point is to move focus away from a specific identity that characterises the actor and instead focus on the situational aspects of this specific type of initiative.

For some of the Somali associations in Sweden campaigning against khat and its use is one of the main activities.

'Swedish-Somali women in Rinkeby [a suburb to Stockholm] have for a long time lobbied for harsher punishments [to apply] against the trade of the chew-drug khat' (Svenska Dagbladet, 16 July, 2007).

One way anti-khat campaigners can employ moral entrepreneurship is to engage in the public debate about khat or speak out against khat when interviewed by journalists. As representatives of the Somali community, they can convey a certain type of knowledge grounded in personal experiences of khat use within the community. This knowledge reaches the public through daily newspapers and has the potential to influence policymakers.

Within the articles analysed, khat use is framed in a negative light. Anti-khat campaigners, police and customs officers, politicians and medical experts are given a voice to enumerate the harms caused by khat use. There is an interplay between the goals of the voluntary associations and the goals of the authorities. The focus is on how to stop the khat trade and to show how khat use plays a major part in the difficulties of members of the Somali community to integrate into Swedish society. Anti-khat campaigners work together with the police and the social services to inform the Somali community of the dangers of khat use. One police officer is quoted as saying: 'My opinion is that khat always makes the family situation more difficult. There are simply more reasons for fights, both within the family and with other men /.../' (Svenska Dagbladet, 27 June, 2003, italics added). In this quote khat is constructed as the cause of violence or social unrest. One social worker claims that addiction to khat is comparable to any other drug:

'We can ascertain that this drug addiction is just as serious as any other. Many families suffer. To reach out with information is the way you have to work, to drive home the thought that this 
is a problem' (GT, 6 February, 2001, italics added).

The quote above is significant since it implies that khat use is not seen as a problem within the Somali community, and that it is the task of the social workers to inform the community of the problem they have at hand. Taken together, the articles analysed gives the impression that the antikhat campaigners, the police and the social services are united against an unknown (but nonetheless discursively significant) proportion of Somali khat (ab)users. This is particularly clear since user voices are largely excluded from the discourse. This sense of an anti-khat coalition has been noted elsewhere, as Anderson and colleagues have put it:

$1 / . . /$ the Somali campaigners provide an indispensable alibi for the coalition of professionals, researchers, bureaucrats and politicians of all colours that their intentions are for the greater good of vulnerable populations, untainted by the cynical politics of race' (Anderson et al. 2007: 193).

The anti-khat campaigners are social actors who can use the criminalisation in Sweden as a yardstick to evaluate the use of khat, having come to the conclusion that khat use is both wrong and undesirable. As one Somali activist says: '[Using khat] is one of our traditions. But it is a bad tradition and we must make those who chew understand that' (Svenska Dagbladet, 27 June, 2003). This quote can be linked to the one above and stresses the importance of 'drug educators' both inside and outside of the community. Their task is to enlighten the users about the problem of khat use, which constructs khat as something inherently bad and specifically detrimental to the social cohesion of Somali families.

\section{Harm to families}

'To chew khat is a common problem among Somali families. How common it is no one really knows. Some say that every second Somali man chews khat, others say that it is perhaps 30 per cent. But the fact that the drug causes great difficulties in an already vulnerable group is clear. - I have seen many families split up because of khat, says Zahra Bihi, who has worked with informing and shaping opinion against khat in Sweden for ten years' (Narkotikafrågan, 2006/5-6, italics added).

The above quote is taken from an investigative article about khat published in the journal of a Swedish NGO that lobbies for a more restrictive drug policy. It is worth quoting at length since it neatly summarises the general discourse on khat in Sweden, specifically facilitating the views of anti-khat campaigners. Far more attention is given to the negative effects of khat use on the families than for example negative physical or mental effects to the individual user. It is worth noting that use is implicitly equivalent to problematic use. Generally, there is no distinction made between use and problematic use in the Swedish khat discourse (cf. Sykes et al. 2010: 6). Words such as addiction, dependency, use, abuse and 'chewing' are used interchangeably, all denoting problematic use. These sentiments about the effects of khat on the family unit are continually reproduced within the discourse about khat. This central theme is echoed by sentences similar to this: 'the addiction often has social effects: families break apart and the household economy is ruined' (Svenska Dagbladet, 30 January, 2012). One Somali campaigner working in a project against khat is quoted, implying a patriarchal structure in Somali families:

'- The men becomes lazy, and they cannot care for their family. The women and children feel bad and the economy is ruined. The abuse costs a lot of money and can in extension lead to divorces /.../' (Expressen, 20 June, 2007, italics added).

Family is central to the discourse about khat use in Sweden and could perhaps be seen as an 
affect of a general family oriented way of life (cf. Johnsdotter 2002: 39).

\section{Use is spreading}

There are further concerns that the use of khat will spread to the majority population:

'[This drug] will spread [to the rest of society] if nothing is done. The police is very passive and close their eyes to the abuse, but when others begin to use the drug hopefully there will be a change [in the attitude of the police]' (Mitt i Tensta-Rinkeby, 2 December, 2008).

Another campaigner argues for stricter sentences: 'There must be a true zero-tolerance against khat. Two-three months in prison does not deter' (Svenska Dagbladet 16 July, 2007). Anti-khat campaigners can argue that use within the Somali community increases and is spread to specific groups:

'Khat has become a part of our culture here in Sweden. Before this was not the case. Many of us feel very excluded in Sweden. Now the youngsters who were born here have started to imitate the elderly and chew more khat. Even the women chew /.../ and the well-educated' (Göteborgs-Posten, 6 October, 2003, italics added).

One representative from a Somali association compares the problem of khat use in Sweden to HIV, invoking a very serious analogy, as well as noting the detrimental effects on families:

'Those who chew khat do not care anymore. They do not care about the children or the family, nor their economy or the future. They just sleep all day long /.../ For the roughly 30000 Somalis in Sweden the African plant drug is a problem comparable to HIV, if not as deadly is Osman's opinion. /.../ This is very dangerous for society, but so far no one has investigated how dangerous /.../' (Sydsvenska Dagbladet, 4 December, 2003).

\section{Discussion}

In a broader context, the mobilisation against khat could perhaps be related to general sentiments within the Somali diaspora in the West. Peter Hansen (2012) has studied the discourse about khat among 'professionals' returning to Somaliland from the diaspora in Europe and North America. These are men and women who has been able to establish themselves in Western countries and who can use their university degrees and experiences of living in the West to seek employment within the international development field (Hansen 2012: 2). 'To many "professionals" the widespread consumption of khat represents the most serious challenge to the further development and democratisation of Somaliland' (Hansen 2012: 2, italics in original). Hansen found that female 'professional' returnees to Somaliland are among the strongest critics of khat use (Hansen 2012: 7). ${ }^{3}$

Hansen's findings are not directly transferable to the situation in Sweden, but they highlight a potential tension between well-educated and integrated members of the diaspora and those who are socially marginalised. This can be compared with the quote above about how khat use is seen as spreading even to the 'well-educated' Somali immigrants. To be an elected representative of a Somali association, working together with the authorities against khat use, could possibly be a source of increased status within the community. Social anthropologist Sara Johnsdotter stresses the 'tremendous importance these organisations have in immigrant groups where few have paid work', and notes that 'these organisations then turn into alternative spheres for building individual careers' (Johnsdotter 2002: 27). One hypothesis concerning the anti-khat sentiments among the well-educated diaspora groups could be that speaking out against khat use might be a way to implicitly distance oneself from the more socially marginalised members of the Somali community. Drawing on Hansen's research, a further exploration of how amassed cultural, social and symbolic capital (Bourdieu 1990) acquired in the diaspora might influence perceptions about khat is needed. 
It is noteworthy that the anti-khat campaigners align themselves with the official Swedish drug policy aim of a drug-free society (cf. Sahlin 2011: 79pp). As such, one might potentially see antikhat campaigning as a strategy of integration into Swedish society. One common view is that the police and the authorities do not take the problem of khat use seriously since it only concerns the Somali immigrant group. In Sweden, the concept of harm reduction is highly contested and officials who are in favour of such measures risk being pejoratively labelled as 'drug liberals'. Members of parliament have lobbied the EU to impose a union-wide ban on khat since the Netherlands and the UK acts as transit countries. Two Christian democrats put forward a central measure to combat khat in an opinion piece, suggesting that Sweden should 'clearly indicate its rejection of the view of drug liberal countries' (Svenska Dagbladet, 25 August, 2009). The antikhat campaigners actively promote a discourse that is against khat to put pressure on the authorities to act with more draconian measures to curb khat use, much in line with the Swedish official goal of a drug-free society.

Something must be said about discursive shifts and counter-voices within the discourse about khat in the articles analysed. The two central themes presented in this article are not the only ones present within the discourse, but they are in my view the most interesting ones. The effect of khat use on employment and individual negative health effects caused by the pharmacology of khat is also commonly discussed. My assessment is that there is an unusually high degree of intertextuality (Fairclough 1992: 102-103) within the discourse, meaning 'the relatively stable networks which texts move along, undergoing predictable transformations as they shift from one text type to another' (Fairclough 1992: 84). Interestingly, articles that pose more complex questions and bring up other issues can be found in specialised journals about drug issues. These articles are often written by journalists reporting from England, where of course a different legal framework exists and where it is seemingly easier to get in contact with actual khat users (cf. Larsson 2007: 30-34). Nonetheless, the discourse about khat as presented in the daily newspaper articles is uniform to a very high degree and tends to reproduce taken-for-granted 'truths' about khat that has already been presented in other articles.

\section{Conclusion}

Khat is constructed as a powerful negative symbol within the discourse and the driving force behind this could be defined as moral entrepreneurship. Several negative aspects of khat use are constantly reproduced in the articles analysed, such as the impact on employment and specific physical and social harms. How khat causes the break-up of Somali families is especially prevalent. Voices from actual users of khat are excluded to the extreme and harm reduction or treatment issues are seldom discussed. The moral entrepreneurship employed could be problematic if the construction of khat as a scapegoat risks increasing stigma and marginalisation within the Somali immigrant community (cf. Anderson et al. 197-198). Discursively, there is a sense of a coalition between anti-khat campaigners and the authorities, which legitimate an image of khat as a highly threatening drug, specifically within the social spectrum. On a general level, this construction of khat created by representatives of Somali voluntary associations, the police, 'drug educationalists' and social workers among others might have implications for the integration of the Somali community in Sweden. The knowledge constructed by way of moral entrepreneurship could potentially be used in ways that have excluding or marginalising effects:

'Specialist drug knowledges and forms of drugs expertise, such as those of pharmacists, lawyers, drug educationalists, criminologists, physicians and others, unquestionably provide something of use to the life of society in general. But such official (often state-sponsored) knowledges are all too readily, and sometimes alarmingly, co-opted into social and political systems of oppression, exclusion and criminalisation /.../' (Boothroyd 2006: 17). 
Generally, research about khat shows that its status within the Somali diaspora is ambivalent. Does it constitute a time-honoured cultural practice and social glue or is it a pernicious drug that breaks families apart and causes social misery? That depends on whom you ask, and since the media discourse about khat in Sweden excludes user voices, the answer to the question seems clear enough. Khat has become a powerful symbol of the difficulties that the Somali immigrant groups face in Swedish society. The intertextuality within the khat discourse has the potential of overlooking other aspects that cause marginalisation. The situation Somalis in Sweden face is one of great complexity, as marginalisation, unemployment, low education levels and direct discrimination effect the life of many. Khat as a symbol and as the perceived cause of this tends to reduce and simplify this complexity. In that way khat acts as a convenient scapegoat and moral entrepreneurship constructs a clear dividing line between what is good and bad within the Somali community.

\section{References}

ACMD (2005) Khat (Qat): Assessment of Risk to the Individual and Communities in the UK, London: Advisory Council on the Misuse of Drugs, Home Office.

Anderson, David, Beckerleg, Susan, Hailu, Degol \& Klein, Axel (2007) The Khat Controversy Stimulating the Debate on Drugs, Oxford: Berg.

Becker, Howard S. (1963/1991) Outsiders - Studies in the sociology of deviance, New York: The Free Press.

Bengtsson, Bo (2004) 'Föreningsliv, makt och integration - ett inledande perspektiv' [Associationism, power and integration - an introductory perspective], Föreningsliv, makt och integration - Rapport från Integrationspolitiska maktutredningens forskningsprogram [Associationism, power and integration - Report from the political integration power inquiry research program], Stockholm: Department of Justice.

Boothroyd, David (2006) Culture on drugs - Narco-cultural studies of high modernity, Manchester: Manchester University Press.

Bourdieu, Pierre (1990) The logic of practice, Stanford: Stanford University Press.

Cohen, Stanley (1972/2002) Folk Devils and Moral Panics - The Creation of Mods and Rockers, London and New York: Routledge.

Fairclough, Norman (1995) Media discourse, New York: Oxford University Press.

Fairclough, Norman (1992) Discourse and social change, Cambridge: Polity Press.

Feigin, Anita, Higgs, Peter, Hellard, Margaret \& Dietze, Paul (2012) 'The impact of khat use on East African communities in Melbourne: A preliminary investigation', Drug and Alcohol Review, vol. 31, pp. 288-293.

Gundersen, Tore (2006) 'Bruk av khat i Norge - Nytelse og lidelse -' [Use of khat in Norway enjoyment and burden], NOVA Skriftserie 1/2006, Oslo: Norsk institutt for forskning om oppvekst, velferd og aldring.

Hansen, Peter (2012) 'Khat, Governance and Political Identity among Diaspora Returnees to Somaliland', Journal of Ethnic and Migration Studies, iFirst article, pp. 1-17. 
Johnsdotter, Sara (2002) Created by God. How Somalis in Swedish Exile Reassesses the Practice of Female Circumcision, Lund monographs in social anthropology 10, Lund: Dept. of Sociology, Lund University.

Klein, Axel \& Metaal, Pien (2010) 'A good chew or good riddance - How to move forward in the regulation of khat consumption', Journal of Ethnopharmacology, vol. 132, pp. 584-589.

Klein, Axel, Beckerleg, Susan \& Degol, Hailu (2009) 'Regulating khat—Dilemmas and opportunities for the international drug control system', International Journal of Drug Policy, vol. 20, pp. 509-513.

Larsson, Annika (2007) 'Kat - drog eller grönsak?' [Khat - drug or vegetable?], Alkohol \& Narkotika, nr. 6/2007, pp. 30-34.

Melander, Charlotte (2009) Inom transnationella och lokala sociala världar - Om sociala stödutbyten och försörjningsstrategier bland svensksomalier [Within Transnational and Local Social Worlds - Social support exchange and strategies for earning a living among Swedish-Somalis], Gothenburg: Dept. of Social Work, Gothenburg university.

Odmalm, Pontus (2004) 'Invandrarföreningar som intressekanaler - möjligheter och hinder på lokal nivå' [Immigrant associations as channels of interest - potentials and obstacles at the local level], Föreningsliv, makt och integration - Rapport från Integrationspolitiska maktutredningens forskningsprogram [Associationism, power and integration - Report from the political integration power inquiry research program], Stockholm: Department of Justice.

Osman, Fatumo A \& Söderbäck, Maja V. (2011) 'Perceptions of the use of khat among Somali immigrants living in Swedish society', Scandinavian Journal of Public Health, vol. 39:2, pp. 212219.

Patel, Shilpa L, Wright, Sam \& Gammampila, Alex (2005) Khat use among Somalis in four English cities, London: Home Office.

Pedersen, Anders \& Toudahl, Klaus (2008) 'Når khat fylder for meget - Misbrug i en minoritetsgruppe' [When khat fills too much - Abuse in a minority group], Stof - Tidskrift for stofmisbrugsområdet, nr. 12 2008-2009.

Sahlin, Ingrid (2011) 'Narkotikapreventionens mål och medel' [The ends and means of drug prevention], in Narkotika - Om problem och politik [Narcotics - About problems and politics], (ed.) Olsson, Börje, Stockholm: Norstedts Juridik.

Sykes, Wendy, Coleman, Nick, Desai, Philly, Groom, Carola, Gure, Mohamud \& Howarth, Radhika (2010) Perceptions of the social harms associated with khat use, Home Office Research Report 44, London: Home Office.

\section{Newspaper articles}

Ahnstedt, C.H. (2006) 'Göteborg satsar mot kat (Gothenburg mobilises against khat)', Narkotikafrågan No. 5/6., pp. 20-3.

Expressen (2007, 20 June) Det dolda knarket i Göteborg (The hidden drugs in Gothenburg). 
GT (2001, 6 February) Drogen kat allt vanligare i förorterna. Men kampen mot missbruket växer sig allt starkare (The drug khat more common in the suburbs. But the fight against the abuse grows even stronger).

Göteborgs-Posten (2003, 6 October) Kat splittrar redan utsatta somalier (Khat splits already vulnerable Somalis).

Mitt i Tensta-Rinkeby (2008, 2 December) "Polisen blundar för missbruket" ("The police close their eyes to the abuse")

Svenska Dagbladet (2003, 27 June) Katmissbruket ökar kraftigt (The abuse of khat increases substantially).

Svenska Dagbladet (2007, 16 July) HD-prövning kan skärpa syn på kat (Supreme Court-decision could toughen view on khat).

Svenska Dagbladet (2007, 16 July) Missbruket drabbar familjer (The abuse strikes against families).

Svenska Dagbladet (2009, 25 August) Pressa EU-länder att förbjuda kat (Pressure EU countries to ban khat).

Svenska Dagbladet (2012, 30 January) Ökat sug efter kat (Increased demand for khat).

Sydsvenska Dagbladet (2003, 4 December) Tullen gör rekordbeslag av kat (The customs makes record seizures of khat).

TT (1990, 29 January) Första khatdomarna väntas (First khat sentences await).

\footnotetext{
${ }^{1}$ Statistics received from Statistics Sweden (http://www.scb.se/).

${ }^{2}$ http://www.somsweden.com/ (15 October 2012).

${ }^{3}$ In other contexts, the Islamic faith, particularly the strengthened faith among some women in the diaspora, has been discussed as one reason for the mobilisation against khat within the Somali community (Patel et al. 2005: 28). The Swedish media discourse does not explicitly discuss Islam in relation to khat.
} 